\title{
Hydropower Development in Nepal: Lessons from Past Models
}

\author{
Santa Bahadur Pun
}

\begin{abstract}
In the last six decades since the 1951 overthrow of Rana regime, hydropower development in Nepal was implemented under various models depending on the donors. The 1950s and '60s were the era of bilateralism to be subsumed by multilateralism of the 1970 s and ' 80 s only to be trodden over by liberalization and privatization of the 1990s and 2000. If one were to scrutinize these bilateral, multilateral and liberalized models in the hydropower sector closely, certain interesting patterns emerge. Nepal could well learn lessons from them.

Bilateral model with donors' own agendas
\end{abstract}

The first bilateral hydropower project ${ }^{1}$ (after the Rana overthrow) to provide power in Nepal was the Russian 2.4 MW Panauti Project commissioned in 1965 at a cost of 2.7 crore rupees (NC). ${ }^{2}$ The Russians found the 22 MW Kaligandaki diversion project at Gaidakot too large. ${ }^{3}$ Russia was keen on executing a 10 MW hydropower project and did investigate the Lower Bagmati, but due to lack of data opted for the smaller Panauti Project on the Rossi river where Nepal had already carried out studies. Not to be outdone, the Americans (Russia's cold war rival) also contributed substantially in the transmission line sector. 4 These investments were in the $66 \mathrm{kV}$ double circuit Balaju-Hetauda-Birgunj transmission line, plus the construction of the $11 \mathrm{kV}$ double circuit Ring Mains in Kathmandu. The latter involved nine substations: Balaju, Teku, Patan, Thimi, Bhaktapur, Chahbel and Maharajgunj as the outside ring, and Balaju, Palace, KTwo and Patan as the inner ring.

Historically, however, Nepal's first bilateral agreements were with India on the 1954 Kosi and 1959 Gandak Projects, exclusively designed to cater for irrigation and flood control in India with small irrigation and hydropower components for Nepal. Kosi's 20 MW Kataiya Hydropower Plant, located in India, later de-rated to 13.6 MW due to siltation problems, supplied erratic power to Nepal's eastern industrial hub of Biratnagar only from 1971.5 Similarly Gandak's 15 MW hydropower plant, located in Nepal and normally generating only about 3 to $4 \mathrm{MW}$, was commissioned only in 1979 at a cost of 17 crore rupees (NC) and handed over to Nepal in $1981 .{ }^{6}$

Because of the low six meter canal-fed head, both Kosi and Gandak power stations used bulb type Kaplan turbines and generators of Japanese make, indicating that India did not have the manufacturing capacity. The Indian-aided Trishuli hydropower first-phase 9 MW power plant was commissioned in 1967 with three Yugoslavian units of 3 MW each. The Trishuli 12 MW second phase, commissioned in 1971, had a different set of four Japanese units of $3 \mathrm{MW}$ each. The project cost was 14 crore rupees (IC). ${ }^{7}$ Like the American-Russian rivalry, the 1960 s also witnessed the Indian-Chinese rivalry in hydropower development. China commissioned a slightly smaller 10.05 MW Sunkoshi plant in 1972 at a cost of 10.9 crore rupees (NC). The electro-mechanical equipments, unlike that of India's Trishuli, were all of Chinese make.

By the time the 14.1 MW Indian-aided Devighat Hydropower Project came on line in 1984 at a cost of NRs 75 crores, 8 both the turbines and generators of 4.7 MW each were built by India's own Bharat Heavy Electricals. ${ }^{9}$ India commissioned Bhutan's 336 MW Chukha Hydropower Plant in 1988 with each units of 84 MW built in India itself. ${ }^{\circ}$ In fact, when India commissioned Bhutan's 1,020 MW Tala Hydropower Plant in 2006, each of the 170 MW units was of Indian make.11 The message for Nepal is that over a very short span of time India graduated from being an importer of electro-mechanical equipments to a manufacturer and exporter of equipment with a single unit as large as $170 \mathrm{MW}$.

Kosi and Gandak probably taught Nepal's engineers very little except to have their eyes opened on the inequities of the project benefits and the value of Nepal's rivers drummed in. Trishuli did encourage some of Nepal's engineers at the then Department of Electricity to translate theory into practice. This gave them the confidence to design the 14 MW Devighat Project downstream of Trishuli's tailrace. Even the then Prime Minister Kirtinidhi Bista publicly proclaimed that Devighat would be built with Nepal's own skill and resources. But the Finance Ministry, already suffering from donor-driven mentality, failed to shoulder this responsibility, and Devighat was, instead, handed to India. Devighat would have done what the 20 MW Chilime Project, 30 years later, did to Nepal: catalyze precious local skills and resources to demonstrate that Nepal, too, has the capacity to build. 


\section{Multilateral model with strings attached:}

With the inequities of the bilateral Kosi and Gandak Project models, Nepal decided that the next river, the Karnali, would have a different, more beneficial model. ${ }^{12}$ UNDP was requested to help in the study of Karnali Chisapani and the Japanese consultant, Nippon Koei, was given the task. This heralded the arrival of Snowy Mountains Engineering Corporation (SMEC), Norconsult, etc., which was followed by the multilateral banks. The World Bank picked up the 6o MW Kulekhani Project while the Asian Development Bank picked up the first $132 \mathrm{kV}$ Gandak-Hetauda transmission line with the Hetauda-Narayanghat road and the Chitwan Pump Irrigation. The initially estimated US\$68 million Kulekhani cost escalated nearly double the amount to US $\$ 122.6$ million when completed.13,14 Badly bitten by the Kulekhani costs, the World Bank itself "escalated" the estimated cost of Marsyangdi to US\$338 million to later announce that the cost on completion in 1989 at US\$294 million was less than the estimated cost. The World Bank, however, admitted that this was "a very high US $\$ 4,260$ per $\mathrm{kW}$ installed". ${ }^{15}$

In 1982, the Asian Development Bank (ADB) for its Fourth Power Project (Butwal-Nepalgunj line) inserted a covenant that says: "the Nepalese government was required to decide on the reorganization of the electricity supply sector and the creation of a new institutional structure acceptable to the Bank." Furthermore, in 1984, the ADB's Fifth Power Project (Duhbi-Anarmani line) stated that "the Government proposed that all these bodies (Electricity Department, Nepal Electricity Authority [sic, Corporation] and various semi-autonomous development Boards) be merged into a single entity, NEA." The World Bank 'integrated the same condition' of the ADB in the agreement concerning the Marsyangdi project. These two multilateral banks were working in tandem, though one could discern that they were not on the same wavelength. When the World Bank pursued the US\$1,082.3 million $201 \mathrm{MW}$ Arun III, the ADB, despite allocating US\$127.6 million for the project, publicly stated that while Arun III was in their minds, it was Kali Gandaki-A that was in their heart! Thus when the World Bank walked away from Arun III "as the risks to Nepal were too great", ${ }^{16}$ it was Kali Gandaki-A that catapulted to the forefront with the ADB easing out the World Bank as the lead agency from Nepal's power sector.

The multilateral banks reveled in macro and micro management of Nepal's power sector for three decades. For Kulekhani, Marsyangdi and the aborted Arun III, Nepal had to increase her tariff seven times in a decade in the following manner: ${ }^{17} 1985-35 \%, 1986-22 \%, 1988-18 \%, 1992-61 \%, 1993-25 \%, 1994-$ $38 \%$ and $1995-20 \%$. The rate of return not on historically depreciated assets but regularly revalued assets methodology was used. Foreign consultants with designs and specifications suitable for foreign contractors of developed countries ruled the roost. These foreign consultants were overseen by a panel of peer consultants. Then there was the inevitable "sleaze money" of the local agents that further pushed the project costs up to ultimately make Nepal's electricity tariff in 1999 by the World Bank's own account 18 "one of the highest in the region". However, the involvement of the multilateral banks in Nepal did have positive aspects as well, in the form of a nearly 10-fold increase in generation capacity, an east-west country length high voltage transmission line and, above all, the exposure of Nepal to the latest know-how in engineering and the construction of hydropower plants.

\section{Liberalization and privatization model with strings in different avatar!}

With the liberalization of the power sector through the Electricity Act of 1992, the Khimti and Bhote Koshi Projects, under the questionable MOU route, emerged on the scene. While many are aware of the dollar denominated and US consumer price index escalated tariff, the other subtleties of "a liberalized power sector" are yet to be fathomed. The key lenders to both these projects are the International Finance Corporation (IFC), an affiliate of the World Bank, and the Private Sector Window of the Asian Development Bank. Khimti's initial 1994 'signed, sealed and done' power purchase agreement (PPA) at US5.20 cents per unit was literally thrown out of the window by these two international lenders, though their very own representatives 'silently witnessed'throughout the night the finalization of the PPA and project agreement. The dollar-denominated loans that have been availed to the developers were all at exorbitant rates of as high as $10-11 \%$ in view of "the country risks"-the fragile political environment of Nepal. These are clearly the 'strings attached' avatar of the liberalized model.

Take the case of the export-dedicated 750 MW West Seti Project pursued by Snowy Mountains Engineering Corporation (SMEC) for the last 12 years. It is reported that the private sector window of ADB has a $20 \%$ equity stake in the US $\$ 1.2$ billion project. ${ }^{19}$ Apparently, both the ADB and SMEC have impressed Nepal's Finance Ministry to pick up a 15\% equity equivalent to US\$45 million "to ensure that the project moves forward". At a time when Nepal is undergoing load shedding and Nepal Electricity Authority is still looking forward to government backing for the execution of the 309 MW Upper Tamakoshi Project, such 
generosity of the Finance Ministry to an export dedicated project is indeed very intriguing. ${ }^{20}$ One can only say that the "charms of market forces" are really at work. Again, take the case of the 2001 hydropower policy that has a quaint definition for hydropower projects for "non-commercial" category. According to that policy, a non-commercial operation is the "generation of power by a public sector utility owned by a foreign country and the power so generated exported to that same foreign country." Project developers up to 1,000 MW built on a "non-commercial basis" need to provide only $15 \%$ energy as royalty in lieu of cash. These are some of the 'strings attached avatars' that Nepal has to face in the liberalized power sector. The successful implementation by Nepalese developers (Indrawati, Chilime, Piluwa, Chakukhola, Sunkosi, Rairang, Khudi, Baramchi, etc.) of smaller projects, the untouchables, to the tune of about $40 \mathrm{MW}$, is the silver lining in the new hydropower policy. However, both the ministries of Water Resources and Finance have their eyes and ears glued to larger projects with 'foreign investors'.

The global competitive bidding for the 402 MW Arun III and 300 MW Upper Karnali Projects resulted in an extremely good response from Indian private firms: ${ }^{21}$ Reliance Energy, Tata Power, Larsen \& Tourbo, Sutlej Power, Jai Prakash Industries, GMR India, Jindal Power, etc. On the Upper Karnali Project, GMR India has reportedly offered $33 \%$ free equity with $7.5 \%$ free energy. ${ }^{22}$ (However, the agreement has been signed with Govt. of Nepal for the offer of $12 \%$ free eneregy and $27 \%$ free equity on 24th Jan. $2008-E d .{ }^{23}$ ) Similarly, Jindal Power has reportedly offered $21.9 \%$ free energy throughout the generation license period on Arun III. Such offers by IPPs on run-of-river projects, set far over and above what Nepal's 2001 hydropower policy envisaged, clearly emphasize the inadequateness of that policy. Such attractive projects are not meant for Nepal's own domestic use. They are meant for export purposes to churn other industries so that their goods and services would be more competitive than those of Nepal. This, I believe, is the lacuna that needs to be rectified in our present liberalized power sector policy. It is also reported that with the government still indecisive, rightly or wrongly, over the Arun III and Upper Karnali bids, ${ }^{24}$ the financially muscular Indian IPPs have taken the path of least resistance by purchasing major shares of Nepalese companies that already have the survey licenses in their pockets: i.e., India's GMR and Bhilwara Energy tying up with Nepal's Himtal and Triveni, respectively.

\section{Conclusion}

To conclude, both bilateral and multilateral models with strings attached did help Nepal's power sector and thus her economic activities. But they had down side effects, too, like foreign consultants, foreign contractors and foreign equipment that pushed up the electricity tariffs, at one time by as high as $61 \%$. Both bilateral and multilateral models did very little to encourage utilization of indigenous skills and resources; or, to be fair, the government totally failed on this count. Within the last six or seven years, when the Maoist insurgency was at its peak, 40 MW of valuable power was availed by the local developers. The government, however, continues to see these local developers as 'untouchables', and is completely mesmerized by foreign investors who are keen to export power across the border at dirt cheap rates. When Khimti's power is now pegged at over US 8 cents per unit, Nepal is forced to chip in US\$45 million to West Seti that will sell peaking power to India at less than US 5 cents per unit. This, of course, does not mean non-implementation of export oriented projects.

The strategy should be, first, to upgrade the local 'untouchables' to the Vaisya or even Chhetri status; i.e., jump from 20 MW to 60/80 MW projects through local resources and skills. Secondly, fulfill Nepal's remaining domestic demands through foreign investments, if need be with government guarantees. It is intriguing why the government, despite a crippling load shedding regimen, is withholding its guarantee to NEA on Upper Tamakoshi. Without the NEA guarantee, the Employees' Provident Fund would have never financed the 20 MW Chilime Project. Then, and only then, should Nepal embark on export-oriented projects, one by one. This step-by-step approach would give Nepal the opportunity and leverage to remedy the mistakes made in the preceding projects. The World Energy Council believes that liberalization of the power sector is beneficial, but this has to be undertaken with caution and care. And in Nepal's present fragile political environment, with extreme caution and care!

Santa Bahadur Pun has served in the power sector for more than three decades. He spent a major portion of his career in the $O \&$ \& $M$ field and was the former Managing Director of Nepal Electricity Authority. He has published numerous papers and articles in various topics concerning water and energy sectors.

Corresponding address: santapun@ntc.net.np

Notes 
1 Great Britain provided the electro-mechanical equipment to both the $500 \mathrm{~kW}$ Pharping (1911 AD) and the $640 \mathrm{~kW}$ Sundarijal (1935 AD) power stations.

2 Nepal Electricity Authority, Generation Report, August 2004. Throughout the article, All rupee figures given as 'NC' refer to Nepalese Rupees, and as 'IC' indicate Indian Currency.

3 Ram Prasad Nepal, former Chief Engineer of Electricity Department.

4 Mihaly, E.B., 1965, Foreign Aid and Politics in Nepal, London: Royal Institute of International Affairs. Oxford University Press.

5 Record of Discussion between Madhusudan Dhakal, Secretary/MOWR, HMGN and MG Padhye, Secretary/irrigation, GOI at Kathmandu from 19th to 24th April 1983.

6 Op.cit., footnote 2.

7 Ibid.

8 This figure is from Nepal Electricity Authority's Generation Report of Bhadra 2061 (August 2004) and is substantially different from ICRs 29 crores as published in Partnership in Economic Development, An Enquiry into the Indian Aid Policy to Nepal 2005, by B.P. Koirala, published by the India Nepal Foundation, Embassy of India, Kathmandu.

9 Op.cit., footnote 2.

10 www.ptcindia.com

11 Ibid.

12 Op.cit., footnote 4.

13 World Bank, 1985 (July 1), Kulekhani Project Completion Report.

14 Ibid.

15 World Bank, 1996 (May 20), Marsyangdi Implementation Completion Report.

16 World Bank's Press Release on Arun III cancellation, August 3, 1995.

17 World Bank, 1994 (August 29), Staff Appraisal Report on Arun III Hydroelectric Project.

18 World Bank, 2000 (June 27), Implementation Completion Report of Power Sector Efficiency Project.

19 Kantipur (Kathmandu), Baisakh 14, 2064 (April 27, 2007).

20 In fact, Kantipur (Magh 28, 2063/February 11, 2007) quotes Dr. Ram Saran Mahat, Nepal's Finance Minister: "electricity is a commercial sector and foreign investors will come on Upper Tamakosi." It is nearly a year now and despite having numerous hours of load shedding each week, no investors have come to the rescue of NEA!

21 The Kathmandu Post, December 4, 2006.

22 Kantipur (Kathmandu), Baisakh 2, 2064 (April 15, 2007).

23 Kantipur (Kathmandu), Magh 11, 2064 (Jan 29, 2008).

24 Nepal (Kathmandu), Poush 8, 2064 (December 23, 2007). 